\title{
CONTEMPORARY HISTORICAL LITERATURE ON FAMILY AND MOTHERHOOD IN POSTWAR DECADES (1945-1965) ${ }^{1}$
}

\author{
Lyudmila I. Vavulinskaya \\ Institute of Language, Literature and History of the Karelian Research Centre \\ of the Russian Academy of Sciences, Petrozavodsk, Russian Federation
}

\begin{abstract}
Introduction. The paper offers an analysis of historical studies on family and motherhood in post-war decades published in the $21^{\text {st }}$ century, gives an account of the achievements of modern historiography on the subject, outlines the tasks for further studies. These topics have become compelling because of the declining value of motherhood and a prolonged demographic crisis in Russia. Methods. The historiographic analysis in this article is based on the thematic-chronological method supplemented with the systemic, typological and comparative-historical techniques permitting the literature available on the subject to be systematized and analyzed. The article primarily focuses on publications by Russian historians. Analysis. The main specific areas of research on family and motherhood are characterized. It is remarked that the pool of sources available has increased, and new research approaches and practices have been introduced. Contemporary authors have focused their attention on the analysis of the ideological background and principles of the Soviet gender policy, on the machinery of constructing the myth about equality of Soviet women. New aspects have been addressed, such as family private life, domestics role in its functioning, family conflict resolution practices, change in womans biological status over time, socio-ethical meaning of government awards for women, womans image reconstruction in post-war Soviet press. Researchers characterized the various stages in the Soviet family policy, marriage and family relationships in urban and rural communities. Studies on the legislative regulation of the family policy, social support to motherhood and childhood in postwar decades continued. The significance of the measures taken in this period to establish a system of medical aid and social guarantees and benefits for mothers was emphasized. The authors, however, remarked the persistent double work load on women, inequalities in payment rates and career. Results. The substantial progress has been achieved in the coverage of the issue of family and motherhood in two post-war decades. The tendency for multidisciplinary research has been growing; new aspects of the problem have been investigated. At the same time, the issue of the organization of the family welfare system, womens value systems, their attitudes towards the social policy and methods of adaptation to the living conditions should be addressed in more detail.
\end{abstract}

Key words: historiography, family, family policy, matrimony, motherhood, post-war decades.

Citation. Vavulinskaya L.I. Contemporary Historical Literature on Family and Motherhood in Postwar Decades (1945-1965). Vestnik Volgogradskogo gosudarstvennogo universiteta. Seriya 4. Istoriya. Regionovedenie. Mezhdunarodnye otnosheniya [Science Journal of Volgograd State University. History. Area Studies. International Relations], 2020, vol. 25, no. 3, pp. 45-55. (in Russian). DOI: https://doi.org/10.15688/jvolsu4.2020.3.4

\section{СОВРЕМЕННАЯ ИСТОРИЧЕСКАЯ ЛИТЕРАТУРА О ПРОБЛЕМАХ СЕМЬИ И МАТЕРИНСТВА В ПОСЛЕВОЕННЫЕ ДЕСЯТИЛЕТИЯ (1945-1965 ГГ.) ${ }^{1}$}

\author{
Людмила Ивановна Вавулинская \\ Институт языка, литературы и истории Карельского научного центра РАН, \\ г. Петрозаводск, Российская Федерация
}




\section{СССР: ПРОБЛЕМЫ СОВЕТСКОЙ МОДЕРНИЗАЦИИ}

Аннотация. В статье дан анализ опубликованных в XXI в. исторических исследований по проблемам семьи и материнства в Советском Союзе, преимущественно в РСФСР, в послевоенные десятилетия. Отмечены достижения новейшей историографии проблемы, определены задачи ее дальнейшего изучения. Актуальность освещения этих вопросов обоснована обострением проблемы утраты ценности материнства и затяжным демографическим кризисом в современной России. Основное внимание в статье уделено публикациям российских историков. Охарактеризованы ключевые направления исследований по проблемам семьи и материнства, отмечено расширение источниковой базы, применение новых исследовательских подходов и практик. Подчеркнуто, что в центре внимания российских авторов оказались вопросы анализа идейных основ и принципов гендерной политики советского государства, изучение технологий конструирования мифа о равноправии полов в советском обществе. Получили освещение такие новые сюжеты, как частная жизнь семьи, роль домашней прислуги в ее функционировании, практики разрешения семейных конфликтов, изменение биологического статуса женщин во времени, социально-этический смысл государственных женских наград, реконструкция образа женщины в послевоенной советской печати. Исследователи выделили особенности различных этапов советской семейной политики, брачно-семейных отношений в городе и в сельской местности. Продолжилось изучение вопросов нормативно-правового регулирования государственной семейной политики, социальной поддержки материнства и детства в послевоенные десятилетия. Была подчеркнута значимость осуществленных в этот период мер по созданию системы медицинской помощи и социальных гарантий и льгот матерям. В то же время авторы отметили сохранение двойной нагрузки на женщин, неравенства в оплате их труда и профессиональной занятости.

Ключевые слова: историография, семья, семейная политика, брак, материнство, послевоенные десятилетия.

Цитирование. Вавулинская Л. И. Современная историческая литература о проблемах семьи и материнства в послевоенные десятилетия (1945-1965 гг.) // Вестник Волгоградского государственного университета. Серия 4, История. Регионоведение. Международные отношения. - 2020. - Т. 25, № 3. - C. 45-55. - DOI: https:// doi.org/10.15688/jvolsu4.2020.3.4

Введение. В последние десятилетия усилилось внимание исследователей к гендерным проблемам, в частности к брачно-семейным отношениям и материнству. Несмотря на то что «за более чем два века присутствия “женской темы” в отечественной историографии были опубликованы на русском языке тысячи работ, формирующих значительный корпус текстов по женской и гендерной истории России» [19, с. 96], современные исследователи внесли много нового в изучение этой темы с точки зрения как методологических подходов, так и раскрытия неосвещенных ранее ракурсов многогранной проблемы. Появились историографические обзоры, в которых подведены итоги изучения женской темы [11; $18 ; 23 ; 27]$.

В данном исследовании поставлена задача на основе изучения современной исторической литературы, главным образом российской, опубликованной в 2000-2010-х гг., охарактеризовать основные направления и новые аспекты исследований по проблемам семьи и материнства в СССР, посвященных периоду двух послевоенных десятилетий. Актуальность изучения этих вопросов обо- снована обострением «проблемы утраты ценности материнства и, как следствие, затяжным демографическим кризисом в России» [33, с. 38]. Между тем в послевоенные десятилетия советским государством были осуществлены важные меры по формированию системы социального обеспечения семьи, основных форм и методов социальной работы с женщинами, повышению рождаемости, улучшению медицинского обслуживания детей и женщин, организации детских учреждений и ликвидации детской беспризорности. В связи с этим закономерно обращение историков к углубленному изучению данных проблем, обобщение как положительного, так и негативного опыта в области государственной семейной политики, социальной поддержки материнства в послевоенные десятилетия.

Методы и материалы. В качестве основы историографического анализа избран проблемно-хронологический метод, применены также системный, типологический и историко-сравнительный методы, позволяющие систематизировать и проанализировать имеющуюся по проблеме литературу. Основ- 
ное внимание в статье уделено публикациям российских историков.

Анализ. Ориентиры и новые подходы в истории семьи и материнства, результаты и перспективы исследований обобщены в работах историков Л.П. Репиной [25], О.А. Хасбулатовой [35], социологов Е.А. Здравомысловой и А.А. Темкиной $[10 ; 12]$. Ученые сосредоточили внимание на анализе идейных основ и принципов гендерной политики советского государства на разных этапах социалистического строительства, изучении технологий конструирования мифа о равноправии полов в советском обществе. Е.А. Здравомыслова и А.А. Темкина предложили свое толкование основных понятий гендерных исследований и рассмотрели советский гендерный порядок на нескольких уровнях - уровне нормативных актов и официальных идеологий и уровне стратегий индивидов и семей. Советский гендерный порядок был назван этакратическим, поскольку «на всех этапах социалистического строительства государство, осуществляя институциональное и дискурсивное регулирование, выступало гегемонным агентом формирования советского гендера» [10, с. 319].

Современные исследователи обосновали периодизацию гендерных отношений в советском обществе, положив в основу значимые перемены в гендерном укладе. Несмотря на некоторые различия в определении этапов советской гендерной политики, большинством авторов рубежными датами были названы 1917 г., начало 1930-х гг., середина $1950-$ х гг., конец 1980-х гг. [10, с. 303; 21, с. $52-$ 59; 24, с. 93-94].

В числе характерных черт гендерного порядка послевоенного периода исследователи выделяют «мобилизацию женщины на службу государству и партии разными путями как репродуктивной единицы и как рабочей силы» (этакратический контракт «работающая мать») [10, с. 314], «формирование системы жесткого контроля репродуктивной сферы» с целью увеличения рождаемости [21, c. 54], а период после XX съезда партии (1956 г.) охарактеризован как этап «ограниченной либерализации гендерной политики», связанной с «частичным восстановлением частной жизни», «мерами стимулирования рожда- емости» и «усилением государственной поддержки материнства» $[10$, с. 314,$315 ; 13$, с. $161 ; 21$, с. 56]. В то же время исследователи подчеркивают, что политика «оттепели» «не коснулась главного социально-крестьянского вопроса: пенсионного и социального обеспечения (пособия по беременности, оплата больничных листов) колхозников и паспортизации деревни... Перемены пришли только со второй половины 1960-х гг.» [7, с. 9].

Многие авторы связывают коренные изменения в государственной семейной политике с принятием Президиумом Верховного Совета СССР 8 июля 1944 г. Указа «Об увеличении государственной помощи беременным женщинам, многодетным и одиноким матерям, усилении охраны материнства и детства, об установлении высшей степени отличия - звания "Мать-героиня" и учреждении ордена "Материнская слава" и медали "Медаль материнства"» $[6$, с. $33 ; 16$, с. $42 ; 24$, c. 93]. Указ устанавливал обязательную государственную регистрацию брака, сложную процедуру бракоразводного процесса, запрет установления отцовства в отношении детей, родившихся вне брака. «Новая консервативно-охранительная социальная политика государства», как считают многие исследователи, была направлена на укрепление брачных союзов, повышение рождаемости и поддержку материнства [16, с. 42; 28, с. 135]. Часть авторов называет закон «репрессивным», «драконовским», приведшим «к значительному количеству так называемых незаконнорожденных детей» [7, с. 8-9]. Действительно, Указ 1944 г. положил начало осуществлению целой системы мер по поощрению рождаемости и социальной поддержке материнства, широко применявшихся в СССР в последующие годы. С другой стороны, жесткое регулирование государством семейной сферы ставило женщину в неблагополучных семьях ввиду сложности процедуры развода в зависимое положение, а незаконнорожденные дети оказались в неравных условиях по сравнению с детьми, родившимися в семьях. При регистрации они записывались по фамилии матери, которая не могла претендовать на взыскание алиментов на содержание ребенка. Послабления в семейной политике начались с середины 1950-х гг.: отмена запрета 


\section{СССР: ПРОБЛЕМЫ СОВЕТСКОЙ МОДЕРНИЗАЦИИ}

на медицинские аборты (1955 г.), упрощение процедуры развода (1965 г.) и др.

Рассматривая основные направления советской государственной семейной политики в первые послевоенные годы, исследователи отмечают изоляцию советской семьи от внешнего мира, закрепленную Указом Президиума Верховного Совета СССР от 15 февраля 1947 г. о воспрещении браков между гражданами СССР и иностранцами и даже гражданами других социалистических государств [6, с. 34]. На усиление политической интервенции государства во все области жизнедеятельности семьи в послевоенный период обращает внимание Е.А. Шамрина. Исследовательница отметила достижения сформированной во второй половине XX в. системы социального обеспечения, которая характеризовалась всеобщностью, доступностью и равным правом на получение различных видов и форм социальной поддержки. В то же время одной из слабых сторон этой системы названа «полная зависимость от государственных дотаций» [38, с. 20-21].

Современными исследователями был поставлен вопрос об утрате некоторых традиционных функций семьи в послевоенный период, в частности функции социализации подрастающего поколения, заботу о котором «советское государство в целом брало на себя» [6, с. 34-35]. «Результатом этого масштабного социального эксперимента стало падение рождаемости, увеличение количества разводов, снижение воспитательного потенциала семьи» [15, с. 130].

Значительный интерес исследователей вызвали проблемы эволюции семьи и семейной политики в XX веке. А.Г. Волков рассматривает негативные явления в развитии семьи в современной России как «накопленный результат демографических изменений, происходивших в стране на протяжении долгих лет» [5, с. 49], подчеркивая недооценку семьи в жизни общества и человека, а также влияние на нее жесткой демографической политики государства [ограничение свободы развода (1936-1965 гг.), запрещение абортов (1936-1955 гг.), усилия по стимулированию деторождения] [5, с. 54].

В статье О.А Хасбулатовой и А.В. Смирновой определены детерминанты государ- ственной семейной политики, исследовано влияние социально-экономических условий, политических, идеологических, социокультурных факторов и традиций, социальной политики государства на развитие и функционирование семьи. Авторы приходят к выводу, что «советская семья полностью зависела от государства в решении проблем своей жизнедеятельности... что оказалось серьезным препятствием в ходе адаптации семьи к новым социально-экономическим условиям в России после распада СССР» [36].

Одним из важных заключений, сделанных современными исследователями, является то, что «формирование брачно-семейных отношений, новой советской повседневности испытывало серьезное влияние общецивилизационных процессов, происходящих на Западе» [1, с. 11], «тенденции в развитии семьи в СССР вполне соответствовали мировым, а тем более европейским» [13, с. 161]. Ученые отмечают коренное изменение условий жизни населения, социальных норм и стереотипов демографического поведения в послевоенные десятилетия и в связи с этим рост числа неполных семей, малодетность, снижение роли семьи в социализации детей и т. д. Таким образом, становится очевидным, что причины кризиса современной российской семьи связаны не только с предшествующей семейной политикой. Они лежат гораздо глубже и обусловлены общими глобальными социальными изменениями, процессами урбанизации, ростом мобильности населения.

Н.А. Араловец в своих исследованиях затрагивает вопросы брачно-семейных отношений горожан в послевоенные десятилетия, в которых нашли отражение изменения ценностных установок жителей городов на брак и семью во второй половине ХХ в., острые проблемы внутрисемейных отношений, прежде всего родителей и детей [2; 3]. Развитие сельской семьи, изменения в демографическом и семейно-брачном поведении, системе нравственных ценностей сельского населения комплексно проанализированы в монографиях О.М. Вербицкой [4] и Л.Н. Денисовой [7].

Получившие значительное распространение в 1950-1960-е гг. практики разрешения семейных конфликтов путем обращения граждан в общественные организации и партийные 
ячейки рассмотрены в статье Е. Жидковой. На примере типичного промышленного центpa (г. Куйбышев) автор показал, как партийные, профсоюзные организации, общественность (товарищеские суды, дружинники, родительские комитеты предприятий, комиссии содействия семье и школе) боролись за «образцовую советскую семью». Обоснованный теоретический подход к изучению вопроса позволил автору сделать вывод о том, что «вмешательство и регулирование со стороны ближайшего окружения или “коллектива" было частью советского гендерного порядка и интерпретировалось как следствие необходимой защиты интересов семьи, и в первую очередь женщины» [9, с. 269]. К выводу автора можно было бы добавить, что активная деятельность многообразных структур общественного самоуправления граждан в СССР в 1960-е гг. была составной частью решения задач коммунистического строительства, формирования коммунистических общественных отношений и воспитания человека нового общества, выдвинутых XXII съездом партии (1961 г.).

Примечательно обращение современных исследователей к сюжетам и явлениям, считавшимся до этого малозначимыми или просто игнорировавшимися. Историками был поднят вопрос о домашней прислуге как социальном феномене эпохи сталинизма и о влиянии этого социального института на повседневную жизнь советского человека, воспитание детей в семье [14]. А.Р. Клоц на основе привлечения разнообразных источников, в том числе воспоминаний и устных интервью, удалось реконструировать образ няни, сложившийся у советских детей в 1930-1950-е годы. Автор высказал обоснованное мнение о том, что в условиях недостатка дошкольных учреждений и бытовой техники в эти годы институт домашней прислуги оказался функционально необходимым элементом жизни общества. В исследовании приводятся убедительные доказательства того, что частный найм домашней прислуги в рассматриваемый период был достаточно массовым социальным фактом, вынужденной мерой для работающих матерей, а не статусным атрибутом властных кругов.

В поле зрения современных историков и ученых-правоведов оказались вопросы нор- мативно-правового регулирования государственной семейной политики, поддержки материнства и детства [26;28]. Исследователи отмечают, что «в отличие от ранее действовавшего довоенного и военного законодательства сохранение семьи в 1950-90-х гг. достигалось не принятием жестких запретительных административных мер (например, о запрещении абортов и усложнении процедуры развода), а созданием благоприятных условий для ее укрепления» [26, с. 26].

Получили освещение и традиционные проблемы охраны здоровья женщин и детей в послевоенные годы $[21 ; 32 ; 34]$. Подчеркивая значимость осуществленных в послевоенные десятилетия мер по созданию системы медицинской помощи и социальных гарантий и льгот женщинам, имеющим детей, авторы отмечают, что она «просуществовала (при незначительных изменениях) до начала 90-х годов» [30, c. 196]. В то же время исследователи обратили внимание на то, что социальная поддержка матерей в сельской местности в послевоенные годы была незначительной, «там во многом сохраняется традиционный уклад и практики заботы о здоровье и родовспоможении» [21, с. 55].

Новый ракурс в исследовании гендерной истории предложил А.Н. Малинкин, проанализировавший символический социально-этический смысл государственных женских наград [20]. Указ Президиума Верховного Совета СССР от 8 июля 1944 г. установил звание «Мать-героиня», ставшее, наряду со званиями Героя СССР и Героя Социалистического Труда, высшей степенью отличия в СССР. Также были учреждены орден «Материнская слава» и медаль Материнства. «“Женский” блок, традиционно присутствующий в наградных системах многих стран, как справедливо отмечает автор, - в СССР трансформировался в специально выделенный “материнский”, чтобы стать инструментом политики в области рождаемости» [20, с. 109]. Неоднозначно оценивая «материнскую» наградную систему в СССР, А.Н. Малинкин подчеркивает: «Учреждение специального женского наградного блока и “героизация" материнства едва ли содействовали освобождению советских женщин, тем не менее, реально (в том числе благодаря ощутимым льго- 


\section{СССР: ПРОБЛЕМЫ СОВЕТСКОЙ МОДЕРНИЗАЦИИ}

там) повышая престиж многодетных матерей в обществе» [20, с. 113].

В рамках междисциплинарного подхода получили дальнейшее развитие оформившиеся в 1980-е гг. как специальное направление исторических исследований проблемы частной жизни, сексуальных отношений в советскую эпоху $[17 ; 29 ; 37]$. Е.Ю. Зубкова, освещая достижения историографии в этой области, отмечает, что «старый спор о том, была ли частная жизнь в СССР, становится анахронизмом. Вместе с тем остаются другие вопросы, касающиеся специфики ее функционирования в рамках “советского проекта", - о границах приватности, о степени открытости и закрытости частной жизни, степени личной свободы и несвободы граждан в различные периоды советской эпохи» [13, с. 159]. К периоду наибольшего ограничения приватности современные исследователи относят 1930-е гг. - начало 1950-х годов. С середины 1950-х гг., в период либерализации политического режима, массового жилищного строительства, открывшего возможность многим семьям получить собственное жилье, а не комнату в коммуналке, сфера приватности значительно расширяется, начинается «процесс реабилитации или реанимации частной жизни» [13, с. 161], «в то же время контроль над частной сферой, над личностью, сохранялся. Это выражалось, главным образом, в обсуждении фактов личной жизни общественными организациями, которые становились связующим звеном между семьей и властью» [1, с. 20-21].

Новые подходы в изучении проблем семьи и материнства во второй половине XX в. разработаны в статье историка, специалиста по антропометрической истории Б.Н. Миронова [22]. Опираясь на достижения нового направления в науке, родившегося на границе экономики, биологии человека, медицины и физической антропологии, автор проанализировал данные о росте и весе рожениц и их детей и на этой основе оценил изменения в биологическом статусе населения Санкт-Петербурга и его благосостоянии. Исследователь подчеркнул, что «уровень доходов и качество питания являлись важнейшими факторами изменения биологического статуса женщин во времени» и что «биологический статус петербуржцев после окончания Великой
Отечественной войны устойчиво улучшался вплоть до конца 1960-х годов» [22, с. 141, 144].

В исторических исследованиях успешно применялся гендерный подход, предполагающий экспертизу социально-исторических явлений с учетом фактора пола, а также историко-социологический метод. В частности, М.В. Антоновой на основе привлечения данных социологических опросов, осуществленных в 1950-1960-е гг., проанализированы причины вступления в брак, мотивы разводов, отношение советских граждан к институту семьи и брака, семейному быту, распределению социальных ролей в семье [1].

Значимым фактором современной историографии женской темы стало расширение источниковой базы. В исследованиях В.В. Смеюха [31] и А.А. Днепровской [8], осуществленных в рамках социальной истории и исторической антропологии, впервые реконструирован образ женщины в послевоенной советской печати. На основе изучения специальных женских изданий: «Работница», «Крестьянка», «Советская женщина» - проанализировано, как власть формировала образ счастливой советской женщины. Плодотворным оказалось привлечение к исследованию проблем семьи и материнства таких визуальных источников, как карикатуры, рисунки, плакаты, а также обращение многих авторов к произведениям художественной литературы.

Современные исследователи, отмечая заслуги советской историографии в области изучения истории семьи и материнства, критически подошли к устоявшимся мифам, в частности к положению о решении женского вопроса в СССР. На основе анализа конкретных материалов показана существенная дифференциация в оплате труда женщин и мужчин, неравенство в профессиональной занятости, выдвижении на руководящие должности, подчеркнуто, что на всем протяжении советского периода сохранялась высокая загруженность женщин домашним хозяйством.

Результаты. Таким образом, современная историческая литература сделала значительный шаг вперед в освещении проблем семьи и материнства в годы двух послевоенных десятилетий. Расширилась источниковая база, были применены новые исследовательские практики, что позволило пересмотреть 
миф официальной советской пропаганды о решении женского вопроса в СССР. Были выявлены характерные черты советского гендерного порядка, позитивные и негативные стороны государственной семейной политики, ее влияние на трансформацию семьи, обращено внимание на утрату семьей традиционной функции социализации подрастающего поколения и последствия этого процесса.

Усилилась тенденция к междисциплинарным исследованиям, рассмотрению проблем семьи и материнства с разных углов зрения. Исследователи обратились к углубленному изучению новых аспектов многогранной проблемы: частной жизни семьи; практик разрешения семейных конфликтов; влияния на повседневную жизнь советского человека такого социального института, как домашняя прислуга; социально-этического смысла государственных женских наград; изменения биологического статуса женщин во времени и др. Было уделено внимание уточнению периодизации гендерных отношений в Советской России, сделаны важные выводы о том, что процессы, происходившие в семье послевоенных десятилетий, оказали влияние на кризис семьи в современной России, а тенденции в развитии семьи в СССР вполне соответствовали мировым.

В то же время нуждаются в более детальной разработке на общегосударственном и региональном уровнях вопросы организации системы социального обеспечения семьи, ценностной ориентации женщин, их отношения к социальной политике, адаптации к условиям жизни. Следует отметить, что в архивах, особенно региональных, остаются невостребованными целые пласты важнейших документов, которые способны существенно расширить представление о поднимаемых проблемах. Бесценный материал для исследования обозначенных вопросов могут дать интервью с живыми свидетелями тех времен, позволяющие воссоздать подробности как материальной стороны жизни, так и эмоциональных переживаний, настроений людей.

\section{ПРИМЕЧАНИЕ}

${ }^{1}$ Финансовое обеспечение исследования осуществлялось из средств федерального бюджета на выполнение государственного задания Карельско- го научного центра РАН (0225-2018-0011) «Карелия в условиях мира и войны (от Средневековья до наших дней)».

Financial support for the research was provided from the Federal budget for the implementation of the state task of the Karelian Research Centre of the Russian Academy of Sciences (0225-2018-0011) "Karelia in peace and war (from the Middle Ages to the present day)".

\section{СПИСОК ЛИТЕРАТУРЫ}

1. Антонова, М. В. Советская социальная политика: семейно-бытовой аспект. 1950-1960-е годы : автореф. дис. ... канд. ист. наук / Антонова Мария Владимировна. - СПб., 2010. -25 с.

2. Араловец, Н. А. Брак и семья в РСФСР в послевоенные годы / Н. А. Араловец // Российская история. - 2010. - № 4. - С. 55-63.

3. Араловец, Н. А. Городская семья в России во второй половине XX в. / Н. А. Араловец. - М. : ИРИ РАН, 2015. $-360 \mathrm{c}$.

4. Вербицкая, О. М. Российская сельская семья в 1897-1959 гг. (историко-демографический аспект) / О. М. Вербицкая. - М. ; Тула : Гриф и К, 2009. $-296 \mathrm{c}$.

5. Волков, А. Г. Эволюция российской семьи в XX веке / А. Г. Волков // Мир России. Социология. Этнология. - 1999. - № 4. - С. 47-57.

6. Гаврыш, О. В. Приоритетные направления советской государственной семейной политики в $1945-$ начале 1950-х гг. (на материалах УССР)/ О. В. Гаврыш // Альманах современной науки и образования. 2015. -№ 10 (100). - С. 33-35.

7. Денисова, Л. Н. Судьба русской крестьянки в XX веке: брак, семья, быт / Л. Н. Денисова. М. : Памятники ист. мысли, 2007. $-476 \mathrm{c}$.

8. Днепровская, А. А. Образ советской труженицы в первое послевоенное десятилетие (по материалам специальных женских изданий) / А. А. Днепровская // Вестник Омского университета. - 2011. № 1. - C. 91-98.

9. Жидкова, Е. Практики разрешения семейных конфликтов в 1950-60-е годы: обращения граждан в общественные организации и партийные ячейки / Е. Жидкова // Советская социальная политика: сцены и действующие лица, 1940-1985. - М. : Вариант : ЦСПГИ, 2008. -С. 266-289.

10. Здравомыслова, Е. А. Государственное конструирование гендера в советском обществе / Е. А. Здравомыслова, А. А. Темкина // Журнал исследований социальной политики. - 2003. T. 1, № 3/4. - С. 299-321.

11. Здравомыслова, Е. Исследования женщин и гендерные исследования на Западе и в России / Е. Здра- 
вомыслова, А. Темкина // Общественные науки и современность. - 1999. - № 6. - С. 177-185.

12. Здравомыслова, Е. А. Советский этакратический гендерный порядок / Е. А. Здравомыслова, А. А. Темкина // Социальная история. Ежегодник. 2003. Женская и гендерная история. - М. : РОССПЭН, 2003. - С. 436-463.

13. Зубкова, Е. Ю. Частная жизнь в советскую эпоху: историографическая реабилитация и перспективы изучения / Е. Ю. Зубкова // Российская история. - 2011. - № 3. - С. 157-167.

14. Клоц, А. Р. Домашняя прислуга как социальный феномен эпохи сталинизма : автореф. дис. ... канд. ист. наук / Клоц Алиса Ростиславовна. - Челябинск, 2012. $-28 \mathrm{c}$.

15. Королев, С. В. Государственная политика в отношении института семьи в советский период / С. В. Королев // Актуальные тенденции социальных коммуникаций: история и современность : материалы Всерос. науч.-практ. конф. с междунар. участием (Ижевск, 30 окт. 2016 г.). - Ижевск : Удмурт. гос. ун-т, 2016. - С. 130-137.

16. Кузнецова, И. П. Государственная политика в области охраны материнства и детства во второй половине 1940-х - первой половине 1960-х годов (на примере Башкирской АССР) / И. П. Кузнецова // Вестник Челябинского государственного университета. - 2014. - № 8 (337). История. Вып. 59. - С. 41-48.

17. Лебина, Н. Б. Обыватель и реформы. Картины повседневной жизни горожан в годы нэпа и хрущевского десятилетия / Н. Б. Лебина, А. Н. Чистиков. - СПб. : Дмитрий Буланин, 2003. - 344 с.

18. Лиходей, Е. М. Переход от «охраны материнства и детства» к «защите прав детей» в новейшей научной литературе / Е. М. Лиходей // Genesis: исторические исследования. - 2017. - № 6. C. 101-109.

19. Малашкин, А. В. Сводная база данных «Женская и гендерная история России, 18002010 гг.»- свидетельство формирования научного направления / А. В. Малашкин, Н. Л. Пушкарева // Уральский исторический вестник. - 2012. Вып. 3. - С. 96-102.

20. Малинкин, А. Н. Женские награды в России: опыт исследования по социологии наградного дела / А. Н. Малинкин // Мир России. Социология. Этнология. - 2004. - Т. 13, № 2. - С. 96-114.

21. Мельникова, О. О. Социальная политика в сфере репродуктивного здоровья и институционализация заботы в советский и постсоветский период / О. О. Мельникова // Вестник Томского государственного университета. Философия. Социология. Политология. - 2011. - Вып. 1 (13). - С. 52-59.

22. Миронов, Б. Н. Биологический статус женщин Санкт-Петербурга в 1940-2005 гг. (по антропо- метрическим данным о новорожденных и их матерях) / Б. Н. Миронов // Мир России. - 2007. - № 1. C. 99-146.

23. Пушкарева, Н. Л. Русская женщина: история и современность : Два века изучения «женской темы» русской и зарубежной наукой, 1800-2000 : материалы к библиогр. / Н. Л. Пушкарева. - М. : Ладомир, 2002. - 522 c.

24. Рабжаева, М. В. Историко-социальный анализ семейной политики в России ХХ века / М. В. Рабжаева // Социологические исследования. - 2004. № 6. -C. 89-97.

25. Репина, Л. П. «Новая историческая наука» и социальная история / Л. П. Репина. - М. : Изд-во ЛКИ, 2009. - 320 с. - Электрон. текстовые дан. Режим доступа: https:/www.twirpx.com/file/1625674/ (дата обращения: 05.02.2018). - Загл. с экрана.

26. Ростова, О. С. Правовая охрана материнства и детства в советском государстве : автореф. дис. ... канд. юрид. наук / Ростова Ольга Сергеевна. - Саратов, 2007. - 29 с.

27. Рябкова, Е. С. Женщины и женский быт в СССР 1950-1960-х гт. в советской и современной российской историографии / Е. С. Рябкова // Вестник Российского университета дружбы народов. Серия: История России. - 2017. - Т. 16, № 4. - С. 670-685.

28. Седова, Д. В. Правовые основы государственной семейной политики СССР в послевоенное десятилетие / Д. В. Седова // Вестник Екатерининского института. - 2015. - № 1. - С. 134-138.

29. Семейные узы : Модели для сборки : сб. ст. / под ред. С. Ушакина. - М. : Новое лит. обозрение, 2004. - Кн. 1. -632 с. ; Кн. 2. - 520 с.

30. Скворцова, Н. Е. Эволюция государственной политики в сфере охраны материнства и детства / Н. Е. Скворцова, В. А. Лянник, С. Н. Ельская // Университетская Клиника. - 2017. - № 3-1 (24). С. $192-199$.

31. Смеюха, В. В. Женские журналы СССР в 1945-1991 гг:: типология, проблематика, образная трансформация / В. В. Смеюха // Женщина в российском обществе. - 2012. - № 1. - С. 55-67.

32. Степанова, О. В. Охрана здоровья женщин и детей в Алтайском крае (1945 - середина 1960-х гг.) / О. В. Степанова. - Барнаул : Алт. гос. техн. ун-т, 2008. -133 с.

33. Субочева, А. Р. Проблемы современного ценностного отношения к материнству в России / А. Р. Субочева, Н. В. Каргина // Научные труды Московского гуманитарного университета. 2017. - № 1. - С. 33-39.

34. Такташева, Ф. А. Развитие системы охраны здоровья женщин и детей в Сталинградской области в 1945-м - начале 1950-х гг. / Ф. А. Такташева // Известия Волгоградского государственного педагогического университета. - 2015. - № 4 (99). - С. 184-189. 
35. Хасбулатова, О. А. Российская гендерная политика в XX столетии: мифы и реальность / О. А. Хасбулатова. - Иваново : Иван. гос. ун-т, 2005. $-372 \mathrm{c}$.

36. Хасбулатова, О. А. Эволюция государственной политики в отношении семьи в России в XX начале XXI века : (Историко-социологический анализ) / О. А. Хасбулатова, А. В. Смирнова // Женщина в российском обществе. - 2008. - № 3 (48). - С. 3-14. Электрон. текстовые дан. - Режим доступа: https:// womaninrussiansociety.ru/wp-content/uploads/2013/12/ 2008_3_hasbulatova.pdf(дата обращения: 06.03.2019). Загл. с экрана.

37. Чуйкина, С. «Быт неотделим от политики»: официальные и неофициальные нормы «половой» морали в советском обществе 1930-1980-х гг. / С. Чуйкина // В поисках сексуальности / под ред. Е. Здравомысловой, А. Темкиной. - СПб. : Дмитрий Буланин, 2002. - С. 99-128.

38. Шамрина, Е. А. Эволюция государственной системы социальной поддержки семьи во второй половине 40-Х - 90-е гг. ХХ в.: на материалах Воронежской области : автореф. дис. ... канд. ист. наук / Шамрина Екатерина Александровна. - Воронеж, 2012. -23 c.

\section{REFERENCES}

1. Antonova M.V. Sovetskaya sotsialnaya politika: semeyno-bytovoy aspekt. 1950-1960-e gody: avtoref. dis. ... kand. ist. nauk [Soviet Social Policy: Family and Household Aspect. 1950s - 1960s. Cand. hist. sci. abs. diss.]. Saint Petersburg, 2010. 25 p.

2. Aralovets N.A. Brak i semya v RSFSR v poslevoennye gody [Marriage and Family in the RSFSR in the Postwar Years]. Rossiyskaya istoriya, 2010, no. 4, pp. 55-63.

3. Aralovets N.A. Gorodskaya semya v Rossii vo vtoroy polovine $X X v$. [Urban Family in Russia in the Second Half of the $20^{\text {th }}$ Century]. Moscow, IRI RAN, 2015.360 p.

4. Verbitskaya O.M. Rossiyskaya selskaya semya v 1897-1959 gg. (istoriko-demograficheskiy aspekt) [The Russian Rural Family in 1897-1959 (Historical and Demographic Aspect)]. Moscow, Tula, Grifi K Publ., 2009. 296 p.

5. Volkov A.G. Evolyutsiya rossiyskoy semyi v XX veke [Evolution of the Russian Family in the $20^{\text {th }}$ Century]. Mir Rossii. Sotsiologiya. Etnologiya [Universe of Russia. Sociology. Ethnology], 1999, no. 4, pp. 47-57.

6. Gavrysh O.V. Prioritetnye napravleniya sovetskoy gosudarstvennoy semeynoy politiki $\mathrm{v}$ 1945 - nachale 1950-kh gg. (na materialakh USSR) [Priority Directions of the Soviet State Family Policy in 1945 - the Early 1950s (By the Materials of the Ukrainian Soviet Socialist Republic)]. Almanakh sovremennoy nauki i obrazovaniya, 2015, no. 10 (100), pp. 33-35.

7. Denisova L.N. Sudba russkoy krestyanki v $X X$ veke: brak, semya, byt [Fate of a Russian Peasant Woman in the Twentieth Century: Marriage, Family, Everyday Life]. Moscow, Pamyatniki istoricheskoy mysli Publ., 2007. 476 p.

8. Dneprovskaya A.A. Obraz sovetskoy truzhenitsy $\mathrm{v}$ pervoe poslevoennoe desyatiletie (po materialam spetsialnykh zhenskikh izdaniy) [Image of a Soviet Working Woman in the First Post-War Decade (Based on Special Womens Publications)]. Vestnik Omskogo universiteta [Herald of Omsk University], 2011, no. 1, pp. 91-98.

9. Zhidkova E. Praktiki razresheniya semeynykh konfliktov v 1950-60-e gody: obrashcheniya grazhdan v obshchestvennye organizatsii i partiynye yacheyki [Practices of Resolving Family Conflicts in the 1950s 1960s: Appeals of Citizens to Public Organizations and Party Cells]. Sovetskaya sotsialnaya politika: stseny $i$ deystvuyushchie litsa, 1940-1985 [Soviet Social Policy: Scenes and Actors, 1940-1985]. Moscow, Variant Publ., TsSPGI, 2008, pp. 266-289.

10. Zdravomyslova E.A., Temkina A.A. Gosudarstvennoe konstruirovanie gendera v sovetskom obshchestve [State Construction of Gender in Soviet Society]. Zhurnal issledovaniy sotsialnoy politiki [The Journal of Social Policy Studies], 2003, vol. 1, no. 3/4, pp. 299-321.

11. Zdravomyslova E., Temkina A. Issledovaniya zhenshchin i gendernye issledovaniya na Zapade i v Rossii [Studies of Women and Gender Studies in the West and in Russia]. Obshchestvennye nauki $i$ sovremennost [Social Sciences and Contemporary World], 1999, no. 6, pp. 177-185.

12. Zdravomyslova E.A., Temkina A.A. Sovetskiy etakraticheskiy gendernyy poryadok [Soviet Etacratic Gender Order]. Sotsialnaya istoriya. Ezhegodnik. 2003. Zhenskaya i gendernaya istoriya [Social History. Yearbook. 2003. Women and Gender History]. Moscow, ROSSPEN, 2003, pp. 436-463.

13. Zubkova E.Yu. Chastnaya zhizn v sovetskuyu epokhu: istoriograficheskaya reabilitatsiya i perspektivy izucheniya [Private Life in the Soviet Era: Historiographic Rehabilitation and Prospects for Studying]. Rossiyskaya istoriya, 2011, no. 3, pp. 157-167.

14. Klots A.R. Domashnyaya prisluga kak sotsialnyy fenomen epokhi stalinizma: avtoref. dis.... kand. ist. nauk [Domestic Servants as a Social Phenomenon of the Era of Stalinism. Cand. hist. sci. abs. diss.]. Chelyabinsk, 2012. 28 p.

15. Korolev S.V. Gosudarstvennaya politika v otnoshenii instituta semyi v sovetskiy period [State Policy on the Institution of the Family in the Soviet 
Period]. Aktualnye tendentsii sotsialnykh kommunikatsiy: istoriya i sovremennost: materialy Vseros. nauch.-prakt. konf. s mezhdunar. uchastiem (Izhevsk, 30 okt. 2016 g.) [Current Trends in Social Communications: History and Modernity. Proceedings of the All-Russian Scientific and Practical Conference with International Participation. Izhevsk, October 30, 2016]. Izhevsk, Udmurtskiy gosudarstvennyy universitet, 2016, pp. 130-137.

16. Kuznetsova I.P. Gosudarstvennaya politika $v$ oblasti okhrany materinstva i detstva vo vtoroy polovine 1940-kh - pervoy polovine 1960-kh godov (na primere Bashkirskoy ASSR) [The State Policy in the Field of Maternity and Childhood Protection in the Second Half of the 1940s - the First Half of the 1960s (On the Example of the Bashkir ASSR)]. Vestnik Chelyabinskogo gosudarstvennogo universiteta [Bulletin ofChelyabinsk State University], 2014, no. 8(337), Istoriya [History], iss. 59, pp. 41-48.

17. Lebina N.B., Chistikov A.N. Obyvatel $i$ reformy. Kartiny povsednevnoy zhizni gorozhan $v$ gody nepa i khrushchevskogo desyatiletiya [Philistine and Reform. Pictures of Everyday Life of Citizens During the NEP and the Khrushchev Decade]. Saint Petersburg, Dmitriy Bulanin Publ., 2003. 344 p.

18. Likhodey E.M. Perekhod ot «okhrany materinstva $\mathrm{i}$ detstva» $\mathrm{k}$ 《zashchite prav detey» $\mathrm{v}$ noveyshey nauchnoy literature [The Transition from "Protecting Motherhood and Childhood" to "Protecting the Rights of Children" in the Latest Scientific Literature]. Genesis: istoricheskie issledovaniya [Genesis: Historical Research], 2017, no. 6, pp. 101-109.

19. Malashkin A.V., Pushkareva N.L. Svodnaya baza dannykh «Zhenskaya i gendernaya istoriya Rossii, 1800-2010 gg.»-svidetelstvo formirovaniya nauchnogo napravleniya [Consolidated Database "Womens and Gender History of Russia, 1800-2010" Evidence of the Formation of a Scientific Direction]. Uralskiy istoricheskiy vestnik [Ural Historical Journal], 2012, iss. 3, pp. 96-102.

20. Malinkin A.N. Zhenskie nagrady v Rossii: opyt issledovaniya po sotsiologii nagradnogo dela [Womens Awards in Russia: The Experience of Research on the Sociology of the Award Case]. Mir Rossii. Sotsiologiya. Etnologiya [Universe of Russia. Sociology. Ethnology], 2004, vol. 13, no. 2, pp. 96-114.

21. Melnikova O.O. Sotsialnaya politika v sfere reproduktivnogo zdorovya $\mathrm{i}$ institutsionalizatsiya zaboty v sovetskiy i postsovetskiy period [Social Policy in the Field of Reproductive Health and Institutionalization of Care in the Soviet and Post-Soviet Period]. Vestnik Tomskogo gosudarstvennogo universiteta. Filosofiya. Sotsiologiya. Politologiya [Tomsk State University Journal of Philosophy Sociology and Political Science], 2011, iss. 1 (13), pp. 52-59.
22. Mironov B.N. Biologicheskiy status zhenshchin Sankt-Peterburga v 1940-2005 gg. (po antropometricheskim dannym o novorozhdennykh i ikh materyakh) [The Biological Status of Women in St. Petersburg in 1940-2005 (According to Anthropometric Data on Newborns and Their Mothers)]. Mir Rossii [Universe of Russia], 2007, no. 1, pp. 99-146.

23. Pushkareva N.L. Russkaya zhenshchina: istoriya i sovremennost: Dva veka izucheniya «zhenskoy temy» russkoy i zarubezhnoy naukoy, 1800-2000: materialy k bibliogr. [Russian Woman: History and Modernity: Two Centuries of Studying the "Female Issue" by Russian and Foreign Science, 1800-2000. Materials for Bibliography]. Moscow, Ladomir, $2002.522 \mathrm{p}$.

24. Rabzhaeva M.V. Istoriko-sotsialnyy analiz semeynoy politiki v Rossii XX veka [A Historical and Sociological Analysis of the XX Century Russia Family Policies]. Sotsiologicheskie issledovaniya [Sociological Studies], 2004, no. 6, pp. 89-97.

25. Repina L.P. «Novaya istoricheskaya nauka» i sotsialnaya istoriya ["New Historical Science" and Social History]. Moscow, Izd-vo LKI, 2009. 320 p. URL: https://www.twirpx.com/file/1625674/ (accessed 5 February 2018).

26. Rostova O.S. Pravovaya okhrana materinstva i detstva $v$ sovetskom gosudarstve: avtoref. dis. ... kand. yurid. nauk [Legal Protection of Motherhood and Childhood in the Soviet State. Cand. jur. sci. abs. diss.]. Saratov, 2007. 29 p.

27. Ryabkova E.S. Zhenshchiny i zhenskiy byt $\mathrm{v}$ SSSR 1950-1960-kh gg. v sovetskoy i sovremennoy rossiyskoy istoriografii [Women and Womens Life in the Soviet Union 1950-1960s in the Soviet and Modern Russian Historiography]. Vestnik Rossiyskogo universiteta druzhby narodov. Seriya: Istoriya Rossii [RUDN Journal of Russian History], 2017, vol. 16, no. 4, pp. 670-685.

28. Sedova D.V. Pravovye osnovy gosudarstvennoy semeynoy politiki SSSR v poslevoennoe desyatiletie [Legal Foundations of the State Family Policy of the USSR in the Post-War Decade]. Vestnik Ekaterininskogo instituta [Bulletin of Catherine The Great National Institute], 2015, no. 1, pp. 134-138.

29. Ushakina S. ed. Semeynye uzy: Modeli dlya sborki: sb. st. [Family Ties: Models for Assembly. Collection of Articles]. Moscow, Novoe literaturnoe obozrenie Publ., 2004, book 1. 632 p; book 2. 520 p.

30. Skvortsova N.E., Lyannik V.A., Elskaya S.N. Evolyutsiya gosudarstvennoy politiki v sfere okhrany materinstva i detstva [The Evolution of State Policy in the Field of Maternal and Child Welfare]. Universitetskaya Klinika [University Clinic], 2017, no. 3-1 (24), pp. 192-199.

31. Smeyukha V.V. Zhenskie zhurnaly SSSR v 1945-1991 gg.: tipologiya, problematika, obraznaya 
transformatsiya [Womens Magazines of the USSR in 1945-1991: Typology, Problematics, Figurative Transformation]. Zhenshchina $v$ rossiyskom obshchestve [Woman in Russian Society], 2012, no. 1, pp. 55-67.

32. Stepanova O.V. Okhrana zdorovya zhenshchin i detey $v$ Altayskom krae (1945 - seredina 1960-kh gg.) [Protection of the Health of Women and Children in the Altai Territory (1945 - mid-1960s)]. Barnaul, Altayskiy gosudarstvennyy tekhnicheskiy universitet, 2008. 133 p.

33. Subocheva A.R., Kargina N.V. Problemy sovremennogo tsennostnogo otnosheniya $\mathrm{k}$ materinstvu v Rossii [Problems of Modern Value Attitude to Motherhood in Russia]. Nauchnye trudy Moskovskogo gumanitarnogo universiteta, 2017, no. 1, pp. 33-39.

34. Taktasheva F.A. Razvitie sistemy okhrany zdorovya zhenshchin i detey v Stalingradskoy oblasti v 1945-m - nachale 1950-kh gg. [Development of the System of Protecting the Health of Women and Children in the Stalingrad Region in 1945 - Early 1950s]. Izvestiya Volgogradskogo gosudarstvennogo pedagogicheskogo universiteta [Ivzestia of the Volgograd State Pedagogical University], 2015, no. 4(99), pp. 184-189.

35. Khasbulatova O.A. Rossiyskaya gendernaya politika $v$ XX stoletii: mify i realnost [Russian Gender Policy in the Twentieth Century: Myths and Reality].
Ivanovo, Ivanovskiy gosudarstvennyy universitet, 2005.372 p.

36. Khasbulatova O.A., Smirnova A.V. Evolyutsiya gosudarstvennoy politiki $\mathrm{v}$ otnoshenii semyi v Rossii v XX - nachale XXI veka: (Istorikosotsiologicheskiy analiz) [Evolution of State Policy Towards the Family in Russia in the $20^{\text {th }}-$ Early $21^{\text {st }}$ Century (Historical and Sociological Analysis)]. Zhenshchina $v$ rossiyskom obshchestve [Woman Woman in Russian Society], 2008, no. 3 (48), pp. 3-14. URL: https://womaninrussiansociety.ru/wp-content/ uploads/2013/12/2008_3_hasbulatova.pdf (accessed 6 March 2019).

37. Chuykina S. «Byt neotdelim ot politiki»: ofitsialnye i neofitsialnye normy «polovoy» morali v sovetskom obshchestve 1930-1980-kh gg. ["Life Is Inseparable from Politics": Official and Unofficial Norms of "Sexual" Morality in Soviet Society of the 1930s - 1980s]. Zdravomyslova E., Temkina A., eds. V poiskakh seksualnosti [In Search of Sexuality]. Saint Petersburg, Dmitriy Bulanin, 2002, pp. 99-128.

38. Shamrina E.A. Evolyutsiya gosudarstvennoy sistemy sotsialnoy podderzhki semyi vo vtoroy polovine 40-kh-90-e gg. XX v.: na materialakh Voronezhskoy oblasti: avtoref. dis. ... kand. ist. nauk [Evolution of the State System of Social Support for the Family in the Second Half of the $40 \mathrm{~s}-90 \mathrm{~s}$ of the $20^{\text {th }} \mathrm{C}$. Cand. hist. sci. abs. diss.]. Voronezh, 2012. $23 \mathrm{p}$.

\section{Information About the Author}

Lyudmila I. Vavulinskaya, Candidate of Sciences (History), Senior Researcher, Institute of Language, Literature and History of the Karelian Research Centre of the Russian Academy of Sciences, Pushkinskaya St., 11, 185910 Petrozavodsk, Russian Federation, ludvav@mail.ru, https://orcid.org/0000-0001-6404-7551

\section{Информация об авторе}

Людмила Ивановна Вавулинская, кандидат исторических наук, старший научный сотрудник, Институт языка, литературы и истории Карельского научного центра РАН, ул. Пушкинская, 11, 185910 г. Петрозаводск, Российская Федерация, ludvav@mail.ru, https://orcid.org/0000-0001-6404-7551 